\title{
10. Abbildungsverzeichnis
}

Abb. 1: Urlaubsreisen 1937. Die deutsche Arbeitsfront. NSG »Kraft durch Freude«. Gau Berlin; Abb. 2: Nikolas Benckiser: Das dritte Rom. Vom Kirchenstaat zum Kaiserreich. Mit Bildern und Karten. Frankfurt a. M. 1938; Abb. 3: Reiseland Italien 1 (1933), H. 2, o. S; Abb. 4-5: Heinz Kuhbier (Hg.): Menschen am Wasser. Berlin 1936; Abb. 6: Gustav René Hocke: Das verschwundene Gesicht. Ein Abenteuer in Unteritalien. Leipzig-Markkleeberg 1939. 